\title{
Dermatologic Lesions in Geriatric Patient with Diabetes Mellitus
}

Fitriani Fitriani ${ }^{1 *}$, Inda Astri Aryani ${ }^{1}$, Nopriyati ${ }^{1}$, Damai Trilisnawati ${ }^{1}$, Stella Sunur ${ }^{1}$

${ }^{1}$ Department of Dermatology and Venereology, Faculty of Medicine Universitas Sriwijaya, Dr. Mohammad Hoesin Hospital Palembang, Palembang, Indonesia

\#Correspondence Author Email : fitrianihasan@ymail.com

\begin{abstract}
Introduction: Changes of structure and function in geriatric results in histopathological, physiological and clinical skin changes. The conditions can cause morbidity and decrease the quality of life of patients. Dermatologic lesions in the geriatric have rarely been the subject of scientific research.
\end{abstract}

Aim of study: This study aimed to determine the prevalences of the most common dermatologic lesions in geriatric subjects and diabetes mellitus geriatric patients.

Methods: This study was descriptive observational with cross-sectional design using total sampling method performed among patients in Geriatric Outpatient Clinic, Dermatology and Venereology Outpatient Clinic and geriatric inpatient room in Dr. Mohammad Hoesin Hospital on July-September 2019.

Results: Physiological skin changes in geriatrics include xerosis cutis (13.95\%), seborrheic keratosis $(13.17 \%)$, guttate hypomelanosis $(8.5 \%)$, senile lentigen $(6.97 \%)$, freckle $(2.32 \%)$, periorbital hyperpigmentation $(1.55 \%)$, senile purpura $(0,77 \%)$ and poikiloderma civatte $(0.77 \%)$. The most skin disorder found were lichen simplex chronicus $(11.1 \%)$, pressure ulcers $(9.25 \%)$, senile pruritus $(8.32 \%)$, asteatotic dermatitis $(6.47 \%)$ and candidiasis $(3.7 \%)$. The most common comorbid condition were diabetes mellitus in 16 patients (22.5\%), CVD in 7 patients $(9.9 \%)$, hypertension in 6 patients $(8.5 \%)$, AKI in 6 patients $(8.5 \%)$, and HHD in 4 patients (5.6\%). Dermatologic lesion in DM patient are xerosis cutis $(2.25 \%)$, senile pruritus $(1.50 \%)$, and pressure ulcer $(1.50 \%)$.

Conclusion: Dermatologic lesions are common in geriatric patient. The subjects presented at least one skin disorders. 
ISSN 25980580

Keyword: geriatrics, aging skin, dermatologic lesion

\section{Introduction}

Increased life expectancy causes longer life, leading to complex health problems. The number of elderly people (geriatrics) in Indonesia has increased. In 2000, the population aged $\geq 60$ years amounted to $14,396,745$ people, increasing to $18,043,712$ people in 2010 , and onefifth of the world's population is estimated to be $>65$ years old in 2050. High life expectancy will cause a new problems in society, including an increases in the incidence of chronic diseases, including skin diseases. In geriatrics, the morphology and physiology changes in various organs or systems in the body, one of which is the skin organ. Geriatric skin changes can be histological, physiological or clinical. Histological changes cause a decreased number of skin cells, a larger size of skin cells, and a reduced amount of intracellular fluid. Physiological changes cause thinning skin due to loss of fat tissue, dry skin due to decreased regeneration ability, fragile, discoloration due to decreased blood flow in to the skin. Senile lentigines, seborrheic keratosis, senile purpura, and Campbell de Morgan spots can be found in geriatric skin. Geriatric skin disorders include: pressure ulcer, pruritus, infections, infestations, dermatitis, photodermatosis, neoplasms, immunology, psychodermatosis, vascular disorders, and drug eruptions.[5,6]

Chronic geriatric disease also has increased including hypertension, joint arthrosis, diabetes mellitus (DM), impaired lipid metabolism, and decreased vision. Most DM patients pay less attention to selfcare. The range of 30-70\% of DM patients have involvement of skin disorders during the course of chronic diseases that are influenced by skin microvascular in DM. Dermatologic lesion in DM patients include pruritus, diabetic lipoid necrobiosis, granuloma anulare, diabetic dermopathy, scleroderma-like syndrome, acantosis ni gricans, and diabetic bulla. The condition is caused by metabolic changes such as hyperglycemia, hyperlipidemia, progressive vascular, neurological, or immune system damage. Study Wambier in Brazil 2014 evaluated 500 DM patients from 2003 to 2004 demonstratd that 97\% of the patients had at least one skin disorders. The most common dermatologic lesions reported among DM patients are tinea pedis (35\%), candidiasis of the skin/nail (26\%), pigmentation disorders (22\%), xerosis (22\%), and tinea unguium (22\%). Goyal et al 2010 in a single center 
observational study at Western Himalayas showed high prevalence of xerosis (44\%) in DM patients. The dermatologic lesions of geriatric in South Sumatera have never been reported. The aim of the study to describe the dermatologic lesions of geriatric with diabetes melitus to increase our concern in geriatric's skin issues which affect their life expectancy.

\section{Methods}

Observational descriptive study with cross-sectional design was used for this study. The sample was obtained using total sampling method between July to September 2019 at Dr. Mohammad Hoesin Hospital Palembang. The inclusion criteria were (1) geriatric patients with skin disorders who visited Geriatric Outpatient Clinic and Dermatology and Venereology Outpatient Clinic (2) geriatric patients with skin disorders who were hospitalized in Geriatric Inpatient Room, (3) patients were willing to participate in this study and willing consent to be photographed after oral or explanations were given. The exclusion criteria were (1) Geriatric patients with skin disorders undergoing treatment (2) Geriatric patients with a dubious diagnosis of skin disorders. Complete history taking was performed on patients with a history of chronic systemic disease. Diagnosis of skin disorders was based on history taking and clinical examination. Demographic characteristics such as age and sex were recorded. Further identifications such as physiological skin changes, skin disorders, and comorbidities were also recorded. Ethical approval was obtained from the Sriwijaya University of South Sumatera, Indonesia with ethical clearance No.254/kepkrsmhfkunsri/2019. Data analysis using software IBM SPSS version 22.0. Documentation of this study was obtained using a Samsung pocket camera 20.0 megapixel.

\section{Results}

This study used primary data on 80 patients who visited the Geriatric Outpatient Clinic, Dermatology and Venereology Outpatient Clinic, and geriatric inpatient room of Dr. Mohammad Hoesin Hospital Palembang during the three-month study period. In this sudy, the most subjects in age range 60-74 years old (72.5\%) with average age was 70 years old, the youngest age was 60 years old and the oldest age was 92 years old. Based on gender, there were 45 female patients $(56.25 \%)$ and 35 male patients $(43.75 \%)$ with male-female ratio was 1,08: 1. (Table 1) 
ISSN 25980580

Table 1. Patient demographic characteristics

\begin{tabular}{llcc}
\hline Demographic Data & & Amount $(\mathbf{n}=\mathbf{8 0})$ & Percentage $(\%)$ \\
\hline Age & $60-74$ & 58 & 72.5 \\
& $75-90$ & 21 & 26.25 \\
\multirow{3}{*}{ Gender } & $>90$ & 1 & 1.25 \\
& female & 45 & 56.25 \\
& male & 35 & 43.75 \\
\hline
\end{tabular}

The subjects in this study had more than one type of physiological skin changes or skin disorders. The most common physiological skin changes were cutaneous xerosis in $13.95 \%$ of subjects, followed by seborrheic keratosis (13.17\%), guttate hypomelanosis $(8.5 \%)$, senile lentigines $(6.97 \%)$, freckles $(2.32 \%)$, periorbital hyperpigmentation (1.55\%), senile purpura $(0.77 \%)$ and poikiloderma of civatte $(0.77 \%)$ shown in Table 2.

Table 3 shows the most common skin disorders found were lichen simplex chronicus $(11.1 \%)$, pressure ulcers $(9.25 \%)$, senile pruritus $(8.32 \%)$, asteatotic dermatitis $(6.47 \%)$ and candidiasis $(3.7 \%)$.

Table 2. Distributions of physiological skin changes in geriatrics $(\mathbf{n}=\mathbf{8 0})$

\begin{tabular}{|c|c|c|}
\hline Physiological skin changes & Amount (n) & Percentage $(\%)$ \\
\hline Seborrheic keratosis & 17 & 13.17 \\
\hline \multicolumn{3}{|l|}{ Discoloration } \\
\hline - Guttate hypomelanosis & 11 & 8.5 \\
\hline - Periorbital hyperpigmentation & 2 & 1.55 \\
\hline Xerosis cutis & 18 & 13.95 \\
\hline Senile lentigines & 9 & 6.97 \\
\hline Freckles & 3 & 2.32 \\
\hline Senile purpura & 1 & 0.77 \\
\hline Poikiloderma civatte & 1 & 0.77 \\
\hline Total & 62 & 48 \\
\hline
\end{tabular}

Table 3. Distribution of skin disorders in geriatrics

\begin{tabular}{lcc}
\hline \multicolumn{1}{c}{ Characteristics of skin disorders in geriatrics } & Amount (n) & Percentage (\%) \\
\hline Senile pruritus & 9 & 8.32 \\
Pressure ulcers & 10 & 9.25 \\
Lichen simplex chronicus & 12 & 11.1 \\
Miliaria rubra & 1 & 0.93 \\
Pemphigus foliaceus & 3 & 2.78 \\
Acute urticarial & 2 & 1.85
\end{tabular}


Asteatotic dermatitis

Cellulitis

Atopic dermatitis

Candidiasis

Drug eruption

- maculopapular type

- erythroderma

Irritant contact dermatitis

Basal cell carcinoma

Lichen amyloidosis

Herpes zoster

Postherpetic neuralgia

Neurofibromatosis

Milia

Fibroma mole

Tinea cruris

Prurigo simplex

Scabies

Pitiriasis sicca

Pigmented nevus

Melanocytic nevus

Bullous pemphigoid

Morbus hansen

Seborrheic dermatitis

Lymphoma cutis

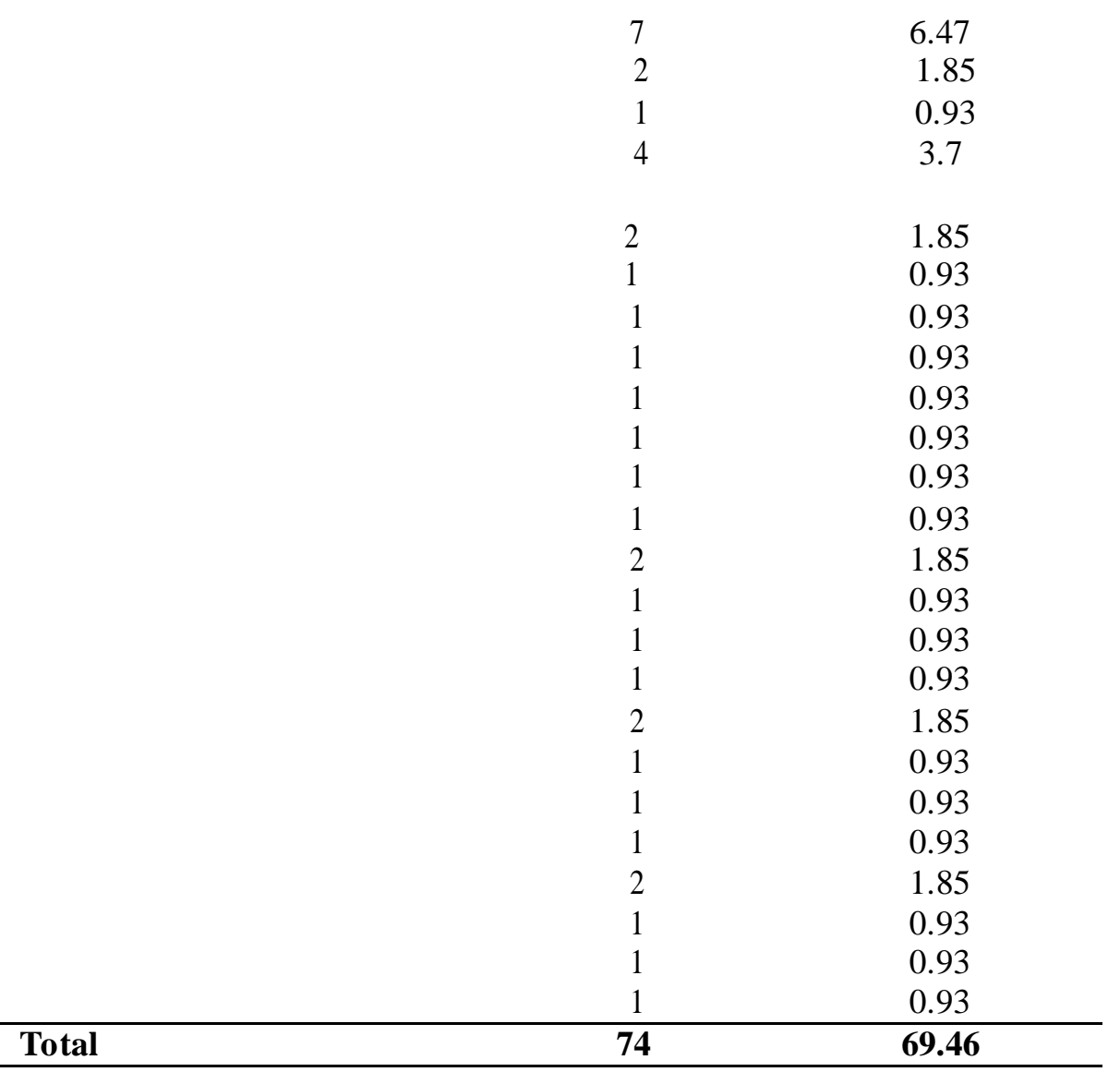

The most comorbidities in the study subjects were 16 patients with diabetes mellitus (22.5\%), 7 patients with Cerebrovascular Disease (CVD) (9.9\%), 6 patients with hypertension (8.5\%), 6 patients with Acute Kidney Injury (AKI) (8.5\%), and 4 patients with Hypertension Heart Disease (HHD) (5.6\%). (Table 4)

Table 4. Distribution of subjects based on comorbidities $(n=80)$

\begin{tabular}{lcc}
\hline \multicolumn{1}{c}{ Comorbidity } & Amount (n) & Percentage (\%) \\
\hline Diabetes mellitus & 16 & 14.8 \\
Hypertension & 6 & 5.55 \\
Comunity acquired pneumonia (CAP) & 3 & 2.77 \\
CVD & 7 & 6.47 \\
Sepsis & 1 & 0.93 \\
HHD & 4 & 3.7 \\
Congestive heart failure (CHF) & 3 & 2.77 \\
Chronic kidney disease (CKD) & 2 & 1.85 \\
Anemia & 3 & 2.77 \\
Carcinoma of Caput Pancreas & 3 & 2.77 \\
Acute delirium syndrome & 3 & 2.77 \\
Dehydration & 2 & 1.85
\end{tabular}




\section{AKI}

$6 \quad 5.55$

Unstable angina pectoris (UAP)

Coronary arteri disease (CAD)

0.93

Insomnia

0.93

Cholelithiasis

0.93

Chronic obstructive pulmonary disease (COPD)

2.77

Osteoarthritis

0.93

Carcinoma of liver

0.93

Colic abdomen

0.93

Achalasia

74

0.93

Total

65.38

Dermatologic lesions in geriatric patient with diabetes mellitus show in Table 5. The most dermatologic lesions are xerosis cutis $(2.25 \%)$, senile pruritus $(1.50 \%)$, and pressure ulcer $(1.50 \%)$.

Table 5. Distribution dermatologic lesions in geriatric patient with diabetes mellitus

\begin{tabular}{|c|c|c|}
\hline Skin lesions in geriatrics with diabetes melitus & Amount & Percentage $(\%)$ \\
\hline Senile pruritus & 4 & 1.50 \\
\hline Xerosis cutis & 6 & 2.25 \\
\hline Acute urticaria & 1 & 0.38 \\
\hline Asteatotic dermatitis & 2 & 0.75 \\
\hline Candidiasis & 1 & 0.38 \\
\hline Pressure ulcer & 4 & 1.50 \\
\hline Herpes zoster & 1 & 0.38 \\
\hline Seborrheic keratosis & 3 & 1.13 \\
\hline Neurofibromatosis & 1 & 0.38 \\
\hline Periorbital hyperpigmentation & 1 & 0.38 \\
\hline Fibroma mole & 1 & 0.38 \\
\hline Freckle & 1 & 0.38 \\
\hline Tinea cruris & 1 & 0.38 \\
\hline Senile lentigines & 1 & 0.38 \\
\hline Prurigo simplex & 1 & 0.38 \\
\hline Senile purpura & 1 & 0.38 \\
\hline Total & 30 & 11.3 \\
\hline
\end{tabular}

\section{Discussion}

Indonesian's life expectancy continues to increase, resulting in a substantial increase in the elderly/geriatric population. Changes in the structure and function of the skin in geriatrics can cause abnormalities.

Physiological skin changes were found in most of subjects. Xerosis cutis was found $13.95 \%$ (18/80), followed by seborrheic keratosis $13.17 \%$ (17/80), and guttate hypomelanosis 
$8.5 \%(11 / 88)$ (Figure 1). Aging causes an increase in the incidence and severity of xerosis cutis. Dry skin in geriatrics is due to reduced sebum levels, sweat gland activity and NMF, and increased transepidermal water loss (TEWL). Maturation and adhesion of abnormal keratinocytes cause loose corneocytes thus providing characteristics of scaly skin. Another factor that has an important role in skin changes is environmental factors such as chronic sun exposure and low humidity and the presence of underlying systemic diseases.[3,5,13]
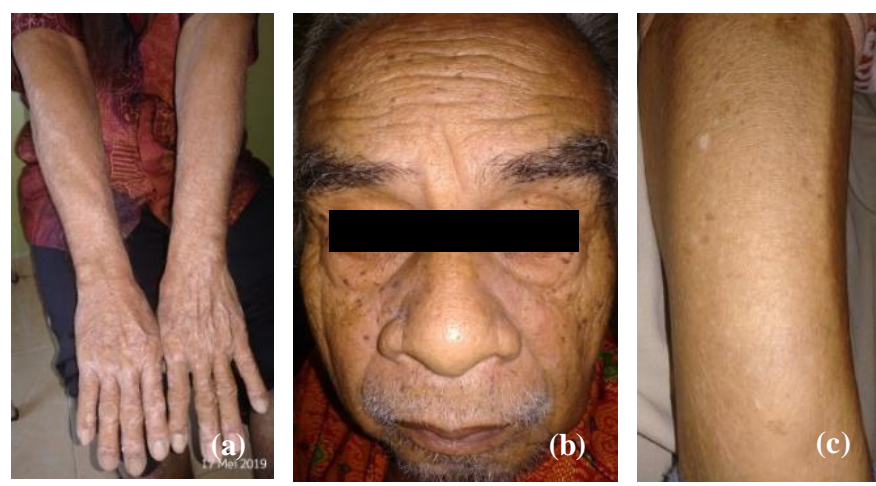

Figure 1. The most physiological skin changes in Geriatrics (a) xerosis cutis (b) seborrheic keratosis (c) guttate hypomelanosis

Seborrheic keratosis is a benign papule or plaque with varying size and color. The amount of seborrheic keratosis increases with aging, even in the absence of sun exposure. Seborrheic keratosis is considered as a biological marker of intrinsic aging. Seborrheic keratosis is very common in white races, and males and females are equally affected.[28] Seborrheic keratosis described as a proliferation of clonal keratinocytes and melanocytes, as the result of focal epidermal hemostasis loss. Seborrheic keratosis has no possibility of malignant transformation. Lesions are often brown or black papules or plaques found in trunk, face, and proximal limbs.[3] Seborrheic keratosis, senile lentigo and wrinkles in geriatrics are considered to be normal conditions in dermatology.[27] Guttate hypomelanosis is usually found in geriatrics at age 40-50 years old. The prevalence of guttate hypomelanosis increased from $47 \%$ at age $31-40$ years old to $97 \%$ at age $81-90$ years old. Women were reported having more gutata hypomelanosis than men. The cause of gutata hypomelanosis is unclear. There are several factors that influence guttate hypomelanosis, such as senile degeneration, chronic sun exposure, genetic factors, trauma and autoimmune. The lesions are round or annular depigmented macules, well-defined borders, white as porcelain sometimes with black dots, smooth surface, and $0.2-2 \mathrm{~cm}$ in diameter. There are several lesions found, especially in areas 
exposed to sunlight such as anterior parts of lower limbs, lower abdomen, upper dorsal arms, and face.[3,28] The pigmentation disorders in the skin are usually due to changes in the distribution of melanin pigments and melanocyte proliferation, and decreased melanocyte function causes accumulation of irregular melanin in basal cells of the epidermis. Besides that epidermal turn over decreased causes longer duration of skin cells to absorb melanin which results in pigmentation spots on the skin.[4]

In addition to physiological skin changes in geriatrics, there are pathological skin disorders that are grouped into skin disorders due to physical factors, infectious skin diseases, infestation skin diseases, dermatitis, photodermatosis, neoplasms, autoimmune diseases, psychodermatosis, vascular disorders, drug eruptions and skin diseases due to nutritional deficiencies.[5] The most common skin disorders found in this study were lichen simlex chronicus $(11.1 \%)$, pressure ulcers $(9.25 \%)$, senile pruritus $(8.32 \%)$, asteatotic dermatitis $(6.47 \%)$ and candidiasis $(3.7 \%)$. (Figure 2 )
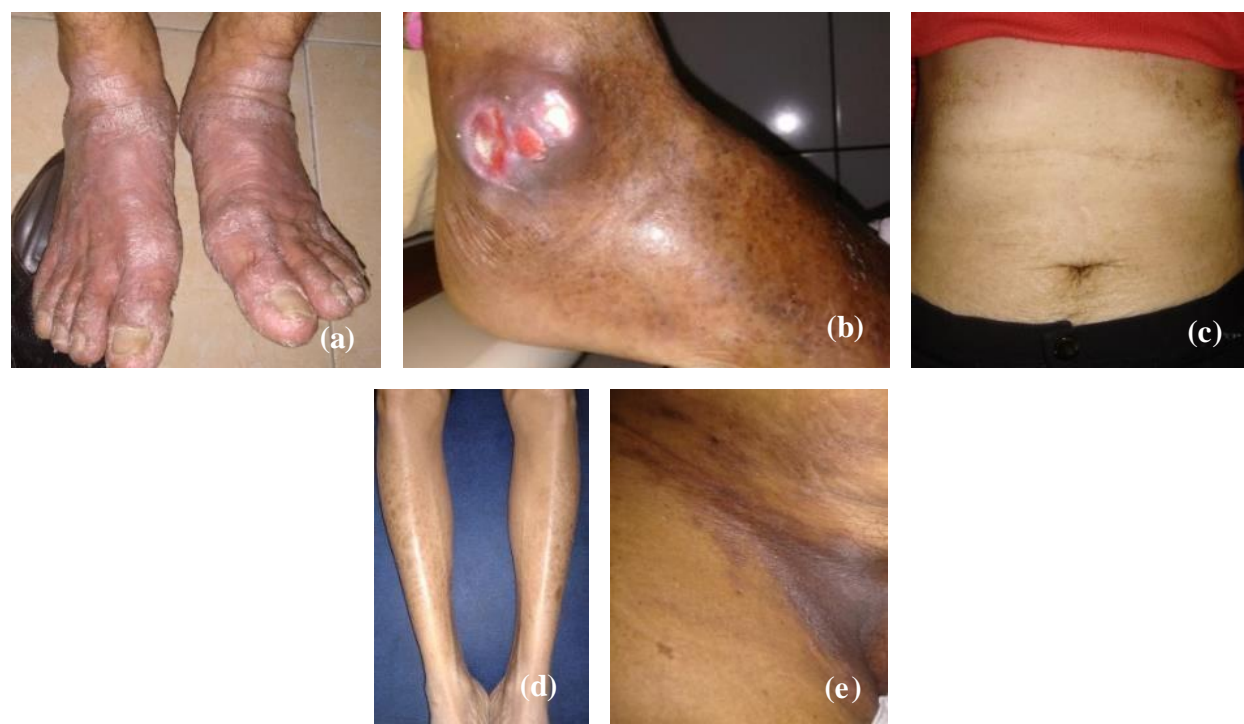

Figure 2. The most skin disorders in Geriatrics (a) lichen simlex chronicus (b) pressure ulcers (c) senile pruritus (d) asteatotic dermatitis (e) candidiasis

The increased incidence of psychodermatosis is probably related to xerosis and pruritus, which has a high incidence in this study. The role of psychological factors such as stress and fatigue is very important to increase lesion progressivity. Lichen simlex chronicus is a chronic inflammation which causes itchy skin. The characteristics of the lesion are thickening of the skin and circumscribed lichenification due to repetitive scratching or rubbing, commonly found 
at age $>60$ years. Early lesions of lichen simlex chronicus are erythema and edema or papules in groups. The most common areas are on self-accessible areas of the body such as the scalp, nape, extensor extremities, wrists, and anogenital areas.[5] Pressure ulcers are skin disorders that are often found in geriatrics, especially in patients with impaired mobility, quadriplegia, end-stage cancer, diabetes mellitus, chronic kidney failure, vascular insufficiency, incontinence, immunosuppressive, hypoalbuminemia, and malnutrition.[5,13] Pressure ulcers are five times higher in geriatrics with malnutrition or hypoalbuminemia.[13] Pressure ulcers are necrosis of tissue involving the skin and underlying structures such as subcutaneous tissue, muscle, and bone.[13] Loss of subcutaneous fat deposits, reduced collagen tissue and elasticity and decreased capillary collateral efficiency causes the skin to become thin and fragile, bone bulges are more pronounced especially in the sacrum, ischial tuberosity, trochanter, heels, and lateral malleolus so they are prone to trauma.[3,13,14] Pruritus is the most common symptom reported in geriatrics especially age $\geq 80$ years old, with the prevalence is $29 \%$. Pruritus is often triggered by low humidity, excessive bathing or application of irritants to the skin.[4] In 10$50 \%$ of cases, pruritus is caused by systemic disorders such as liver disease, hypothyroidism, iron deficiency anemia, uremia, polycythemia, leukemia/lymphoma, and kidney failure.[3,5,14]

Various types of skin infections are often found in geriatric patients. This is due to a decrease and dysregulation of immune function related to aging which contributes to increased geriatric susceptibility to infection. In this study, candidiasis $(3,7 \%)$ and tinea cruris $(0,93 \%)$ are the most common types of skin infections. The high incidence of fungal infections in geriatric patients in this study is may be caused by a hot climate and high humidity in the Palembang region. Many cases of tinea cruris are found in tropical climates and are often exacerbated by the use of occlusive clothing and high humidity. The presence of underlying systemic diseases such as diabetes mellitus with dermatophyte or candida infections should be concerned.[29]

Scabies was found in $1.85 \%$ of subjects. Scabies is caused by Sarcoptes scabiei mites. Transmission can be through direct or indirect contact with the affected person's clothing materials. The clinical picture of scabies in geriatric patients varies greatly. Many patients are misdiagnosed because the symptoms are sometimes not typical. This is due to some geriatric 
patients also suffering from asteatotic dermatitis or xerosis cutis which is accompanied by complaints of pruritus.[26]

Superficial bacterial infection of the skin due to Staphylococcus and Streptococcus bacteria can be found in geriatric patients. Bacterial infections such as cellulitis were found in 2 patients $(1.85 \%)$. Cellulitis is a bacterial skin infection commonly found in geriatrics. Aggravating diseases such as diabetes mellitus and resistance to antibiotic use should be noted.[26]

Viral infection such as herpes zoster was found in $0.93 \%$ of subjects. Herpes zoster (HZ) is the most common viral infection of geriatrics. This infection often occurs due to impaired immune function and the reactivation of varicella zoster virus. The incidence of $\mathrm{HZ}$ increases with age. Incidence of 2.5 per 1000 patients age $20-50$ years old increased to 7.8 per 1000 patients at age $>60$ years old and reached 10 per 1000 patients per year at the age of 80 years old. Herpes zoster in geriatrics often causes complications such as post herpetic neuralgia (PHN). This disorder often persists for several months to years after the skin lesions heal. PHN incidence is in the range of $10-70 \%$ of $\mathrm{HZ}$ cases. $[5,13,26]$ In this study, PHN cases were found as much as $0.93 \%$ of subjects.

Drug eruption is commonly found in geriatrics due to an increased tendency to use several drugs for various diseases. This causes drug reactions, especially on the skin. Drug eruption consists of exanthema with maculopapular, morbilliform, or erythematous lesion types. Other drug eruption are vasculitis, fixed drug eruptions, erythema mul tiforme, urticaria, contact dermatitis, purpura and photodermatitis.[5] In this study, drug eruption was found in $2.78 \%$ subjects with $1.85 \%$ maculopapular type and $0.93 \%$ erythroderma.

Autoimmune diseases that are commonly found in geriatrics are bullous pemphigoid and pemphigus vulgaris. Chronic vesicobullous skin disorders due to autoimmune such as bullous pemphigoid was found in $1.85 \%$ of subjects and pemphigus foliaceus was found in $2.78 \%$ of subjects. Bullous pemphigoid is found mostly at age $>60$ years old. Increased circulating antibodies to hemidesmosome protein in epidermis causes epidermal-dermal separation and results in bullae. Pemphigus vulgaris is bullous disease which is quite serious in geriatrics because of its high morbidity and mortality due to electrolyte imbalance and secondary infection.[5] 
Geriatric patients often suffer from contact dermatitis. In this study, we found $0.93 \%$ of subjects with contact dermatitis. This is due to reduced langerhans cells, increased T cells, and decreased vascular sensitivity. Another factor that may contribute to this condition is the use of certain ingredients as allergens such as lanolin, paraben esters, dyes, plants, balm, rubber, nickel and topical therapy.[3,26,27]

This study found basal cell carcinoma in $0.93 \%$ of subjects. Benign and malignant skin tumors increase in frequency with increasing age. Benign proliferative lesions which increase in number and size, must be distinguished from pre-cancerous or cancerous lesions. Benign tumors that commonly found in geriatric patients include seborrheic keratosis, skin tags, solar lentigo and cherry angioma, while malignant skin tumor that commonly found is basal cell carcinoma.[26]

The range of $30-70 \%$ of DM patients have skin involvement during the course of the disease affected by microvascular skin in DM. Dermatologic lesions in DM patients can occur before DM is diagnosed, during the course of DM disease, or due to side effects of antidiabetic therapy. In the study, there were 3 most skin abnormalities, namely xerosis cutis $(2.25 \%)$, senile pruritus $(1.50 \%)$, and pressure ulcer $(1.50 \%)$. Skin disorders in DM patients can be caused directly by metabolic changes such as hyperglycemia, hyperlipidemia, progressive vascular damage, neurological, or immune system. Uncontrolled glucose levels affect skin homeostasis, inhibit keratinocyte proliferation and mi gration, protein biosynthesis, induce endothelial cell apoptosis, reduce nitrite oxide (NO) synthesis, and affect phagocytosis and chemokasis of some cells. Hyperglycemia also induces the production of advanced glycation end products (AGEs). Advanced glycation end products are formed from glycation of proteins, lipids, and nucleic acids that induce reactive oxygen species (ROS), affect ROS clearance, function of extra and intracellular proteins, and induce proinflammatory cytokines through the $\kappa \beta$ factor factor (NF$\kappa \beta)$. Advanced glycation end products biochemical interactions are one of the major pathways involved in DM complications, including skin disorders. [21]. AGE alters collagen properties, decreasing flexibility and solubility and increasing its rigidity [22].

Zakharov et al. demonstrated that well-controlled patients with type $1 \mathrm{DM}$ did not presented alteration on the epidermal thickness [29]. This data reinforces that skin disorders in DM patients are strongly related to glycaemia control. The study of Foot et al in Brazil of 403 
ISSN 25980580

DM patients showed that DM patients with uncontrolled blood sugar 94\% had skin abnormalities, whereas only $60 \%$ of DM patients with controlled glucose had skin abnormalities. In the initial phase of DM, skin disorders that often occur in the form of xerosis cutis, callus, and fissure and often undiagnosed. Lack of diagnosis and treatment on early-stage skin disorders can lead to clinical worsening, and progression to foot neuropathy, ulcers and even amputation [35]. Diabetes mellitus induced neuropathy can reach sensory, motor and autonomic pathways, leading to different dermatologic conditions. Neuropathies, alone or simultaneously, can lead to neuropathic foot ulcer, the most severe cutaneous lesion, in consequence of the poor healing potential of DM skin [42]. Cellular damage occurs due to hyperglycemia and hyperinsulinemia, causing a decrease in regulation and proliferation of keratinocytes. In vitro research shows an imbalance in the composition of the stratum corneum which is a decrease in triglycerides and ceramids while fatty acids and cholesterol increase. Other studies have shown an increase in the number of corneocyte layers in the stratum corneum and a decrease in basal cell proliferation and the composition of epidermal DNA resulting in a slowdown in epidermal turnover. The corneocyte surface of DM patients is also greater than the control.

\section{Conclusion}

In this study, we found physiological skin changes in geriatrics such as xerosis cutis $(13.95 \%)$, seborrheic keratosis $(13.17 \%)$, guttate hypomelanosis $(8.5 \%)$, senile lentigines $(6.97 \%)$, freckle $(2.32 \%)$, periorbital hyperpigmentation $(1.55 \%)$, senile purpura $(0.77 \%)$ and poikiloderma of civatte $(0,77 \%)$. The most common skin disorders found in geriatrics are lichen simplex chronicus (11.1\%), pressure ulcers (9.25\%), senile pruritus $(8.32 \%)$, asteatotic dermatitis $(6.47 \%)$ and candidiasis (3.7\%). Dermatologic lesions in DM patients such as xerosis cutis $(2.25 \%)$, senile pruritus $(1.50 \%)$, and pressure ulcer $(1.50 \%)$.

\section{References}

1. Yaar M. Aging of skin. In: Goldsmith LA, Katz SI, Gilchrest BA, Paller AS, Leffel DJ, Wolff K, editors. Fitzpatrick's Dermatology in General Medicine. $8^{\text {th }}$ ed. New York: The Mc Graw-Hill Companies, Inc; 2012. p. 1213-26. 
2. Farage MA, Miller KW, Elsner P. Characteristic of the aging skin. Advances in Wound Care 2013; 2(1): 5-10.

3. Jafferany M, Huynh TV, Silverman MA, Zaidi Z. Geriatric dermatoses: a clinical review of skin diseases in an aging population. IJD 2012; 51(5): 509-522.

4. Khurshid K, Paracha MM, Amin S, Pal SS, et al. Frequency of cutaneous diseases in geriatric population of type IV and V skin. JPM Institute 2012; 26(1): 39-42.

5. Wey SJ, Chen DY. Common cutaneous disorders in the elderly. JCGG 2010; 1(2): 3641.

6. Darjani A, Mohtasham ZA, Amini AK, Golchai J, Sadre AE, et al. Skin disorder among elder patients in a refferal center in Northern Iran (2011). DRP 2013; 1: 1-4.

7. Vandergriff TW. Anatomy and physiology. In: Bolognia JL, Jorizzo JL, Schaver JV, Cerroni L, editors. Dermatology. $4^{\text {th }}$ ed. Edinburg: Mosby; 2018. p. 44-55.

8. Chu DH. Development and structure of skin. In: Golds mith LA, Katz SI, Gilchrest BA, Paller AS, Leffel DJ, Wolff K, editors. Fitzpatrick’s Dermatology in General Medicine. $8^{\text {th }}$ ed. New York: The Mc Graw-Hill Companies, Inc; 2012. p. 58-75.

9. Lapeere H, Boone B, Schepper SD, Verhaeghe E, Gele MV, et al. Hypomelanoses and Hypermelanoses. In: Goldsmith LA, Katz SI, Gilchrest BA, Paller AS, Leffel DJ, Wolff K, editors. Fitzpatrick's Dermatology in General Medicine. $8^{\text {th }}$ ed. New York: The Mc Graw-Hill Companies, Inc; 2012. p. 804-26.

10. Powers JG, Odo L Philips TJ. Decubitus (pressure) ulcers. In: Goldsmith LA, Katz SI, Gilchrest BA, Paller AS, Leffel DJ, Wolff K, editors. Fitzpatrick's Dermatology in General Medicine. $8^{\text {th }}$ ed. New York: The Mc Graw-Hill Companies, Inc; 2012. p. 1121-9.

11. Craft N. Superficial cutaneous infections and pyodermas. In: Goldsmith LA, Katz SI, Gilchrest BA, Paller AS, Leffel DJ, Wolff K, editors. Fitzpatrick's Dermatology in General Medicine. $8^{\text {th }}$ ed. New York: The Mc Graw-Hill Companies, Inc; 2012. p. 2128-47.

12. Schmader KE, Oxman MN. Varicella and herpes zoster. In: Goldsmith LA, Katz SI, Gilchrest BA, Paller AS, Leffel DJ, Wolff K, editors. Fitzpatrick's Dermatology in 
General Medicine. $8^{\text {th }}$ ed. New York: The Mc Graw-Hill Companies, Inc; 2012. p. 2384-401.

13. Schieke SM, Garg A. Superfisial fungal infection. In: Goldsmith LA, Katz SI, Gilchrest BA, Paller AS, Leffel DJ, Wolff K, editors. Fitzpatrick's Dermatology in General Medicine. $8^{\text {th }}$ ed. New York: The Mc Graw-Hill Companies, Inc; 2012. p. 2276-97.

14. Burkhart CN, Burkhart CG. Scabies, other mites, and pediculosis. In: Goldsmith LA, Katz SI, Gilchrest BA, Paller AS, Leffel DJ, Wolff K, editors. Fitzpatrick's Dermatology in General Medicine. $8^{\text {th }}$ ed. New York: The Mc Graw-Hill Companies, Inc; 2012. p. 2569-78.

15. Tardan MPC, Zug KA. Allergic contact dermatitis. In: Goldsmith LA, Katz SI, Gilchrest BA, Paller AS, Leffel DJ, Wolff K, editors. Fitzpatrick's Dermatology in General Medicine. $8^{\text {th }}$ ed. New York: The Mc Graw-Hill Companies, Inc; 2012. p. 15265.

16. Burgin S. Numular eczema, lichen simplex chronicus, and prurigo nodularis. In: Goldsmith LA, Katz SI, Gilchrest BA, Paller AS, Leffel DJ, Wolff K, editors. Fitzpatrick's Dermatology in General Medicine. $8^{\text {th }}$ ed. New York: The Mc Graw-Hill Companies, Inc; 2012. p. 182-7.

17. Calton DA, Liu Z, Diaz LA. Bullous pemphi goid. In: Goldsmith LA, Katz SI, Gilchrest BA, Paller AS, Leffel DJ, Wolff K, editors. Fitzpatrick's Dermatology in General Medicine. $8^{\text {th }}$ ed. New York: The Mc Graw-Hill Companies, Inc; 2012. p. 608-16.

18. Thomas VD, Snavely NR, Lee KK, Swanson NA. Benign epithelial tumors, hamartomas, and hyperplasias. In: Goldsmith LA, Katz SI, Gilchrest BA, Paller AS, Leffel DJ, Wolff K, editors. Fitzpatrick's Dermatology in General Medicine. $8^{\text {th }}$ ed. New York: The Mc Graw-Hill Companies, Inc; 2012. p. 1319.

19. Deo MS, Kerse N, Vandal AC, Jarret P. Dermatological disease in the older age group: A cross-sectional study in aged care facilities. BMJ 2015; 5: 1-6.

20. Alam MN, Husain MA, Siddiqua A, Babar ZUM, Hasan MR. The prevalence of skin and venereal diseases among the geriatric patients attending in a tertiary care Hospital in Dhaka, Bangladesh. BJMS 2019; 18: 130-5. 
21. Hidajat D, Hapsari Y, Hendrawan IW. Karakteristik penyakit kulit pada geriatri di poliklinik kulit dan kelamin RSUD Provinsi Nusa Tenggara Barat periode 2012-2014. Jurnal kedokteran Unram 2017; 6(4): 7-13.

22. Bains P. Skin disorders among elderly population without comorbidities: A hospital based study. Int J Res Dermatol 2019; 5(2): 1-5.

23. Mir MM, Mir MS. Dermatological conditions among the geriatric population: A cross sectional survey. Archieves of Dermatol and Skin Care 2018; 1(1): 18-20.

24. Martin ES, Elewski BE. Cutaneous fungal infection in the elderly. Clin in Geriatric Med 2012; 18(1): 59-75.

25. Nelly JB, Martin A, Simpson N, Maccuish AC. Pruritus in diabetes mellitus: Investigations of prevalence and correlation with diabetes control. Diabetes Care 1986; 9(3): 273-5.

26. Bartling SJ, Naff JL, Canevari MM, Fink CM. Pruritic rashin an elderly patient with uncontrolled diabetes melitus. AACE 2019; 5(2): 146-9.

27. Asokan N, Binesh VG. Cutaneous problems in elderly diabetics: A population-based comparative cross-sectional survey. Indian J Dermatol Venereol Leprol 2017; 83: 20511.

28. Ezejiofor OI, Onayemi O, Olasode OA, Ikem RT. Patterns of dermatological disorders among diabetics. EDOJ 2013; 9(2): 1-14.

29. Collins CD, Hivnor C. Seborrheic dermatitis. In: Golds mith LA, Katz SI, Gilchrest BA, Paller AS, Leffel DJ, Wolff K, editors. Fitzpatrick’s Dermatology in General Medicine. $8^{\text {th }}$ ed. New York: The Mc Graw-Hill Companies, Inc; 2012. p. 260-6.

30. Wambier CG, Takada MH, Foss-Freitas MC, Frade MAC, Foss MC, Foss NT. Effects of metabolic control on cutaneous findings in diabetes mellitus. Revista Brasileira de Medicina Interna. 2014;1:11-9.

31. Goyak A, Raina S, Kaushal SS, Mahajan V, Sharma NL. Pattern of cutaneous manifestations in diabetes mellitus. Indian J Dermatol. 2010;55:39-41. 
ISSN 25980580 